\title{
Facile Synthesis of Bis-Trifluoromethyl 1,8-Dioxo-Octahydroxanthene Derivatives
}

\author{
Cosmas O. Okoro, Mumiye A. Ogunwale, Abiodun S. Oyedele \\ Department of Chemistry, Tennessee State University, Nashville, TN, USA \\ Email: cokoro@tnstate.edu
}

How to cite this paper: Okoro, C.O., Ogunwale, M.A. and Oyedele, A.S. (2019) Facile Synthesis of Bis-Trifluoromethyl 1,8-Dioxo-Octahydroxanthene Derivatives. International Journal of Organic Chemistry, 9, 121-129.

https://doi.org/10.4236/ijoc.2019.93011

Received: July 12, 2019

Accepted: August 10, 2019

Published: August 13, 2019

Copyright (C) 2019 by author(s) and Scientific Research Publishing Inc. This work is licensed under the Creative Commons Attribution International License (CC BY 4.0).

http://creativecommons.org/licenses/by/4.0/

\begin{abstract}
Xanthene and Xanthenediones are structural components of several bioactive and semi-synthetic molecules. This work described an expeditious synthesis of novel and hitherto unreported bis-trifluoromethyl xanthene dione derivatives. The reaction of two equivalents of 5-trifluoromethyl cyclohexane-1,3dione with substituted aromatic aldehydes in the presence of ethanol containing 1 - 2 drops of $\mathrm{HCl}$ was facile under microwave irradiation. Short reaction time ( $25 \mathrm{~min})$, good to excellent yields $(80 \%-95 \%)$, good atom economy, and simple workup are the major advantages of the above procedure. Moreover, the fluorinated products represent synthetically useful stable intermediates that could find applications in pharmaceutical, agricultural and material industries.
\end{abstract}

\section{Keywords}

Xanthenedione, Aromatic Aldehyde, Cyclic $\beta$-Diketone, 5-Trifluoromethyl

\section{Introduction}

Although several reports of 9-phenyl substituted xanthenedione derivatives containing bis-methyl, ethyl, isopropyl, phenyl and hydrogen have appeared in the literature [1] [2] [3] [4], the corresponding bis-trifluoromethyl group have received little or no attention. Several derivatives containing the aforementioned substituents show a wide range of biological activities, such as antidepressant [5], anticholinesterase [6] and anti-cancer [7] [8] activities. The biological activities were shown to depend on the nature of the moiety present at the 9-position of the central pyran ring. The introduction of a phenyl sulfonamide at the above position gave rise to derivatives with antimicrobial [9] [10], antimalarial [11] [12], and antibacterial activities [13] [14] [15] [16]. The replacement of the sulfonamide with a carboxamide generated derivatives with similar activity profile 
as those of sulfonamide but also displayed fungicidal activity [17]. Fluorine atoms attached to organic molecules show "polar hydrophobicity" as described by DiMagno [18] [19] [20] [21] [22]. The above behavior appears to cause the fluoro-alkyl groups to participate in less dispersive interaction with aqueous solvent. Thus, the above property could in part explain the enhanced fluorine-containing small organic molecule binding affinity to a putative protein target. A survey of the literature showed that a typical procedure for the preparation of xanthenes and their 1,8-dioxo derivatives involved the well-known multicomponent reaction of a cyclic $\beta$-diketone with substituted aromatic aldehydes under a variety of reaction conditions. The reported reaction conditions included use of protonic acids [23], Lewis acids $\left(\mathrm{InCl}_{3} \cdot 4 \mathrm{H}_{2} \mathrm{O}\right.$ [24], $\mathrm{FeCl}_{3} \cdot 6 \mathrm{H}_{2} \mathrm{O}$ [25], and $\mathrm{NaHSO}_{4}$ [26]). In other cases, heterogeneous catalysts, such as Dowex-50W, [27] and $\mathrm{NaHSO}_{4} \cdot \mathrm{SiO}_{2}$, [28] were reported. Unfortunately, many of the above methods suffer from a number of drawbacks, such as prolonged reaction conditions, low yields of products, use of hazardous solvent, use of excess catalyst and tedious workup procedure. In continuation of our research program involving the synthesis of fluorine "carrier reagents" and their use for the synthesis of complex trifluoromethyl—containing organic systems of medicinal importance [29] [30] [31] [32] [33]. Herein, we describe the first report of a facile synthesis of 9-(4-phenyl-substituted)-3.6-bis(trifluomethyl-3,4,5,6,7,9-hexahydro- $1 \mathrm{H}$-xanthe ne-1,8(2H)-diones. The above was achieved via condensation of our previously reported 5-trifluorome-thylcyclohexane-1,3-dione with substituted aromatic aldehydes under conventional heating and microwave irradiation.

\section{Experimental}

\subsection{Material and Methods}

Melting points were determined using capillary melting apparatus, MELT-TEMP and were uncorrected. Infrared (IR) spectra were recorded on 1600 Model FTIR spectrophotometer. All IR spectra were obtained as neat samples. Proton $\left({ }^{1} \mathrm{H}\right.$ $\mathrm{NMR})$ and carbon $\left({ }^{13} \mathrm{C} \mathrm{NMR}\right)$ nuclear magnetic resonance spectra were taken on Bruker ARX 400 NMR instrument with tetramethylsilane as an internal standard. Chemical shifts are reported in parts per million $(\delta)$, and signals were expressed as s (singlet), d (doublet), dd (doublet of doublet), $t$ (triplet), q (quartet), $\mathrm{m}$ (multiplet). Coupling constant are in hertz (HZ). Mass spectra of the compounds were recorded on Varian Saturn 2000 GC/MS. The reaction was done using a brand of microwave oven manufactured by CEM corporation. Each reaction was monitored and judged complete by removing aliquots at intervals and analyzed by thin layer chromatography (TLC).

\subsection{Synthesis}

\subsubsection{General Procedure for the Synthesis of Compounds 3a-3j}

A mixture of 5-trifluoromethyl-1, 3-cyclohexanedione 1 (2.0 mmol), and appropriate aldehyde $2(1.0 \mathrm{mmol})$ in $4 \mathrm{ml}$ of ethanol acidified with a drop of concen- 
trated hydrochloric acid was microwaved for 25 minutes in a CEM microwave oven. The completion of the reaction was indicated by TLC, after which the reaction mixture was cooled to room temperature $\left(25^{\circ} \mathrm{C}\right)$ to afford ethanol insoluble solid products. The products were recrystallized from ethanol to afford highly pure products.

4-(1,8-dioxo-3,6-bis(trifluoromethyl) -2,3,4,5,6,7,8,9-octahydro-1 H-xanth en-9-yI) benzonitrile (3a)

$m p: 203^{\circ} \mathrm{C}-204^{\circ} \mathrm{C}$. $\left({ }^{1} \mathrm{H}\right.$ NMR $\left.300 \mathrm{MHz} \mathrm{CDCl}_{3}\right): \delta: 2.36-2.81$ (m, 8H, cyclohexyl-Hs), $2.81(\mathrm{~m}, 4 \mathrm{H}), 2.99\left(\mathrm{~m}, 2 \mathrm{H}, \mathrm{CH}\right.$ next to $\left.\mathrm{CF}_{3}\right), 4.82(\mathrm{~s}, 1 \mathrm{H}, \mathrm{CH}), 7.49$ $7.60\left(\mathrm{~m}, \mathrm{~J}=8.0,4 \mathrm{H}, \mathrm{Ar}-\mathrm{H} ; \mathrm{IR}\right.$ (Nujol): $1659(\mathrm{O}=\mathrm{C}-\mathrm{C}=C-0) \mathrm{cm}^{-1}$ Calc for $\mathrm{C}_{22} \mathrm{H}_{15} \mathrm{~F}_{6} \mathrm{NO}_{3}: \mathrm{C}, 58.03$; $\mathrm{H}, 3.30 ; \mathrm{N}, 3.85 \%$. Found: $C, 57.92 ; \mathrm{H}, 3.22 ; \mathrm{N}, 3.90 \%$.

9-(4-fluorophenyl) -3,6-bis(trifluoromethyl) -3,4,5,6,7,9-hexahydro-1 $H$-xa nthene-1,8(2H)-dione ( $3 b)$

$m p: 177^{\circ} \mathrm{C}-178^{\circ} \mathrm{C} .\left({ }^{1} \mathrm{H}\right.$ NMR $\left.300 \mathrm{MHz}, \mathrm{CDCl}_{3}\right): \delta: 2.36-2.80(\mathrm{~m}, 8 \mathrm{H}$, cyclohexyl-Hs), $2.81(\mathrm{~m}, 4 \mathrm{H}), 2.99\left(\mathrm{~m}, 2 \mathrm{H}, \mathrm{CH}\right.$ next to $\left.\mathrm{CF}_{3}\right), 4.82(\mathrm{~s}, 1 \mathrm{H}, \mathrm{CH}), 7.49-7.60$ $(\mathrm{m}, \mathrm{J}=8.0,4 \mathrm{H}, \mathrm{Ar}-\mathrm{H})$; IR (Nujol): $1666(\mathrm{O}=\mathrm{C}-\mathrm{C}=\mathrm{C}-0) \mathrm{cm}^{-1}$ Calc for $C_{21} \mathrm{H}_{15} \mathrm{~F}_{7} \mathrm{O}_{3}: C$, 56.26; H, 3.37; N\%. Found: $C$, 56.20; H, 3.29\%.

9-(4-chlorophenyl) -3,6-bis(trifluoromethyl) -3,4,5,6,7,9-hexahydro-1 $H$-xa nthene-1,8(2H)-dione (3c)

$m p: 182^{\circ} \mathrm{C}-183^{\circ} \mathrm{C} .\left({ }^{1} \mathrm{H}\right.$ NMR $\left.300 \mathrm{MHz}, \mathrm{CDCl}_{3}\right): \delta: 2.35-2.79(\mathrm{~m}, 8 \mathrm{H}$, cyclohexyl-Hs), $2.81(\mathrm{~m}, 4 \mathrm{H}), 2.99\left(\mathrm{~m}, 2 \mathrm{H}, \mathrm{CH}\right.$ next to $\left.\mathrm{CF}_{3}\right), 4.82(\mathrm{~s}, 1 \mathrm{H}, \mathrm{CH}), 7.49$ 7.60 (m, J=8.0,4H, Ar-H);); IR(Nujol): $1666(O=C-C=C-0) \mathrm{cm}^{-1}$ Calc for $\mathrm{C}_{21} \mathrm{H}_{15} \mathrm{ClF}_{6} \mathrm{O}_{3}$ : $\mathrm{C}, 58.61$; $\mathrm{H}, 3.75 \%$. Found: $\mathrm{C}, 58.58 ; \mathrm{H}, 3.70 \%$.

9-phenyl-3,6-bis(trifluoromethyl) -3,4,5,6,7,9-hexahydro-1 $H$-xanthene-1, $8(2 H)$-dione $(3 d)$

$m p: 200^{\circ} \mathrm{C}-202^{\circ} \mathrm{C}$. $\left({ }^{1} \mathrm{H}\right.$ NMR $\left.300 \mathrm{MHz}, \mathrm{CDCl}_{3}\right): \delta: 2.35-2.79(\mathrm{~m}, 8 \mathrm{H}$, cyclohexyl-Hs), $2.81(\mathrm{~m}, 4 \mathrm{H}), 2.99\left(\mathrm{~m}, 2 \mathrm{H}, \mathrm{CH}\right.$ next to $\left.\mathrm{CF}_{3}\right), 4.82(\mathrm{~s}, 1 \mathrm{H}, \mathrm{CH}), 7.24-$ $7.34(\mathrm{~m}, \mathrm{~J}=8.0,5 \mathrm{H}, \mathrm{Ar}-\mathrm{H}) ; 1676(O=C-C=C-0) \mathrm{cm}^{-1}$ Calc for $C_{21} H_{16} F_{6} O_{3}: C$, 58.61.; H, 3.75\%. Found: $C, 58.58 ; H, 3.70 \%$.

9-ethyl-3,6-bis(trifluoromethyl) -3,4,5,6,7,9-hexahydro-1 H-xanthene-1,8( 2H)-dione (3e)

$m p: 164^{\circ} \mathrm{C}-165^{\circ} \mathrm{C}$. $\left({ }^{1} \mathrm{H}\right.$ NMR $\left.400 \mathrm{MHz}, \mathrm{DMSO}\right): \delta: 2.35-2.79(\mathrm{~m}, 8 \mathrm{H}$, cyclohexyl-Hs), 2.81 (m, $4 \mathrm{H}), 2.99\left(\mathrm{~m}, 2 \mathrm{H}, \mathrm{CH}\right.$ next to $\left.\mathrm{CF}_{3}\right)$ ), $4.82(\mathrm{~s}, 1 \mathrm{H}, \mathrm{CH}), 1.4(\mathrm{~m}$, $5 \mathrm{H}) ;{ }^{13} \mathrm{C}$ NMR (400 MHz, DMSO) $\delta: 193.7,193.5,163.3,162.7,125.8,115.4,115.0$, 40.5, 39.5, 36.1, 35.4, 25.8, 17.7, 14.5; IR (Neat): 2956, 2934, 1663 (O=C:C=C) cm ${ }^{-1}$.

9-(naphthalen-2-yI) -3,6-bis(trifluoromethyl) -3,4,5,6,7,9-hexahydro-1 $\mathrm{H}-\mathrm{x}$ anthene-1,8(2H)-dione (3f)

$m p: 275^{\circ} \mathrm{C}-276^{\circ} \mathrm{C}$. $\left({ }^{1} \mathrm{H}\right.$ NMR $\left.400 \mathrm{MHz}, \mathrm{DMSO}\right): \delta: 2.35$ - $2.78(\mathrm{~m}, 8 \mathrm{H}$, cyclohexyl-Hs), 2.81 (m, $4 \mathrm{H}), 2.99\left(\mathrm{~m}, 2 \mathrm{H}, \mathrm{CH}\right.$ next to $\left.\mathrm{CF}_{3}\right), 4.82(\mathrm{~s}, 1 \mathrm{H}, \mathrm{CH}), 7.1-8.1$ (Naphthalene: $\mathrm{m}, \mathrm{J}=7.2,1 \mathrm{H}, \mathrm{J}=7.5,3 \mathrm{H}, 7=8.0,3 \mathrm{H}) ;{ }^{13} \mathrm{C}$ NMR $(400 \mathrm{MHz}$, DMSO) $\delta: 193.1,193,162.1,162,161.7,142.3,133.3,131.3,128.2,127.4,126.2$, 117.4, 40.6, 40, 36.3, 36, 26.9; IR (Neat): 3057, 1665(O=C:C=C), $1108 \mathrm{~cm}^{-1}$.

9-(p-tolyl) -3,6-bis(trifluoromethyl) -3,4,5,6,7,9-hexahydro-1 H-xanthene$1,8(2 H)$-dione $(3 g)$ 
$m p: 191^{\circ} \mathrm{C}-192^{\circ} \mathrm{C} .\left({ }^{1} \mathrm{H}\right.$ NMR $\left.400 \mathrm{MHz}, \mathrm{DMSO}\right): \delta: 2.35$ - 2.79 (m, 8H, cyclohexyl-Hs), $2.81(\mathrm{~m}, 4 \mathrm{H}), 2.99\left(\mathrm{~m}, 2 \mathrm{H}, \mathrm{CH}\right.$ next to $\left.\mathrm{CF}_{3}\right), 4.82(\mathrm{~s}, 1 \mathrm{H}, \mathrm{CH}), 7.24$ 7.34 (m, J = 7.5, 4H, Ar-H), 2.35 (s, $\left.1 \mathrm{H}, \mathrm{CH}_{3}-\mathrm{Ar}\right) ;{ }^{13} \mathrm{C} \mathrm{NMR}$ (400 MHz, DMSO) $\delta: 193.0,192.0,162.3,161.5,141.0,140.9,136.0,129.1,128.9,116.1,115.9,40.6,40.1$, 40, 36.4, 35.7, 31.4, 25.8, 21.0; IR (Neat): 2925, 1728 (C=O), $1673(\mathrm{O}=\mathrm{C}: \mathrm{C}=\mathrm{C}) \mathrm{cm}^{-1}$.

9-(benzo[d][1,3]dioxol-5-yI)-3,6-bis(trifluoromethyl) -3,4,5,6,7,9-hexahyd ro-1 $H$-xanthene-1,8(2H)-dione $(3 h)$

$m p: 199^{\circ} \mathrm{C}-200^{\circ} \mathrm{C} .\left({ }^{1} \mathrm{H} \mathrm{NMR} 400 \mathrm{MHz}, \mathrm{DMSO}\right): \delta: 2.35-2.79(\mathrm{~m}, 8 \mathrm{H}$, cyclohexyl-Hs), $2.81(\mathrm{~m}, 4 \mathrm{H}), 2.99\left(\mathrm{~m}, 2 \mathrm{H}, \mathrm{CH}\right.$ next to $\left.\mathrm{CF}_{3}\right), 4.3(\mathrm{~s}, 1 \mathrm{H}, \mathrm{CH}), 5.9$ (s, $2 \mathrm{H}), 7.3(\mathrm{~m}, 3 \mathrm{H}, \mathrm{Ar}-\mathrm{H}) ;{ }^{13} \mathrm{C} \mathrm{NMR}(400 \mathrm{MHz}, \mathrm{DMSO}) \delta: 193.1,192.9,162.5$, $162.4,161.8,147.5,147.3,146.2$, 137.9, 137.7, 122.1, 109.3, 101.2, 40.6, 40.0, 36.1, 31.1, 25.8, 25.5; IR (Neat): 2997, 1665 (O=C:C=C), $1488 \mathrm{~cm}^{-1}$.

9-(4-hydroxy-3-methoxyphenyl)-3,6-bis(trifluoromethyl) -3,4,5,6,7,9-hex ahydro-1 $H$-xanthene-1,8(2H)-dione (3i)

$m p: 256^{\circ} \mathrm{C}-257^{\circ} \mathrm{C} .\left({ }^{1} \mathrm{H}\right.$ NMR $\left.400 \mathrm{MHz}, \mathrm{DMSO}\right): \delta: 2.35-2.91$ (m, 8H, cyclohexyl-Hs), $2.81(\mathrm{~m}, 4 \mathrm{H}), 2.99\left(\mathrm{~m}, 2 \mathrm{H}, \mathrm{CH}\right.$ next to $\left.\mathrm{CF}_{3}\right), 4.82(\mathrm{~s}, 1 \mathrm{H}, \mathrm{CH}), 7.24-$ 7.34 (m, J = 8.0, 5H, Ar-H), 8.7 (s, 1H, OH-Ar); ${ }^{13} \mathrm{C}$ NMR (400 MHz, DMSO) $\delta$ : $193.1,193.0,162.2,162.1,147.5,145.7,134.9,128.5,125.9,120.9,116.3,115.5$, 113.2, 56.1, 40.6, 40.1, 39.9, 36.4, 31.0, 25.8, 25.5; IR (Neat): 3367 (OH stretch), 2968, 1738 (C=O), 1663 (O=C:C=C), $1274(\mathrm{C}-\mathrm{O}) \mathrm{cm}^{-1}$.

9-(2,4-dichlorophenyl) -3,6-bis(trifluoromethyl) -3,4,5,6,7,9-hexahydro-1 $H$-xanthene-1,8(2H)-dione (3j)

$m p: 225^{\circ} \mathrm{C}-226^{\circ} \mathrm{C}$. ( ${ }^{1} \mathrm{H}$ NMR $\left.400 \mathrm{MHz}, \mathrm{DMSO}\right): \delta: 2.35-2.71$ (m, 8H, cyclohexyl-Hs), $2.81(\mathrm{~m}, 4 \mathrm{H}), 2.99\left(\mathrm{~m}, 2 \mathrm{H}, \mathrm{CH}\right.$ next to $\left.\mathrm{CF}_{3}\right), 4.82(\mathrm{~s}, 1 \mathrm{H}, \mathrm{CH}), 7.24-$ 7.4 (dd, Ar-H), 8.5 (s, 1H, 2Cl-Ar); ${ }^{13} \mathrm{C}$ NMR (400 MHz, DMSO) $\delta: 192.8,192.7$, $162.6,161.9,161,140.2,134.9,133.2,131.9,128.8,128.7,125.9,114.6,40.6,40.1$, 39.9, 36.1, 35.8, 30.2, 25.8; IR (Neat): 3103, $1684(\mathrm{C}=\mathrm{O}), 1636(\mathrm{O}=\mathrm{C}: \mathrm{C}=\mathrm{C}), 1107$ (C-O) $\mathrm{cm}^{-1}$.

\section{Results and Discussion}

Initially we conducted the reaction using conventional heating in ethanol containing 1 - 2 drops of $\mathrm{HCl}$. The reaction was judged unsatisfactory after three trials, because of low yields, reaction time $(3-4 \mathrm{~h})$, and the need for purification by column chromatography. The corresponding microwave reaction was facile and gave good to excellent yields ( $80 \%$ - 95\%, Figure 1) in $25 \mathrm{~min}$. The purity of each product was confirmed by sharp melting point and characterization by spectroscopic methods (IR, NMR, and GC/MS). Under conventional heating as shown in Scheme 1 the reaction took 3 - $4 \mathrm{~h}$ giving low yield of product. On the otherhand under microwave irradiation as shown in Scheme 2 the reaction was complete in 25 min with good to excellent yields. All products showed strong absorption in the IR spectrum near $1665 \mathrm{~cm}^{-1}$, that is characteristic of a ketone carbonyl in conjugation with a double bond. The molecular ion corresponding to the molar mass of each product was observed as the largest $\mathrm{m} / \mathrm{z}$ peak in each 


\begin{tabular}{|c|c|c|c|c|}
\hline Entry ${ }^{a}$ & $\mathrm{R}$ & Product & Yield (\%) ${ }^{b}$ & $\mathrm{MP}\left({ }^{\circ} \mathrm{C}\right)$ \\
\hline 1 & & $3 a$ & 95 & $203-205$ \\
\hline & & $3 b$ & 90 & $177-178$ \\
\hline 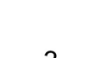 & & $3 c$ & 92 & $182-183$ \\
\hline 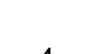 & & $3 d$ & 91 & $200-202$ \\
\hline 5 & & $3 e$ & 88 & $164-165$ \\
\hline & & $3 f$ & 80 & $275-277$ \\
\hline 7 & & $3 g$ & 90 & 191-192 \\
\hline 8 & & $3 h$ & 91 & $199-200$ \\
\hline 9 & & $3 i$ & 91 & $256-257$ \\
\hline 10 & & $3 j$ & 88 & $225-226$ \\
\hline
\end{tabular}

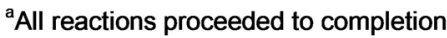

${ }^{b}$ Yield after recrystallization

Figure 1. Physical properties of fluorinated xanthenedione derivatives.

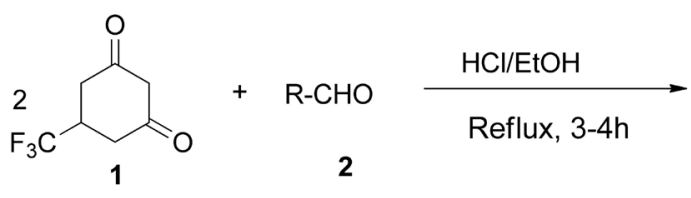

Scheme 1 . Synthesis of 3 by conventional heating.<smiles>[R]C1C2=C(CC(C(F)(F)F)CC2=O)OC2=C1C(=O)CC(C(F)(F)F)C2</smiles> 


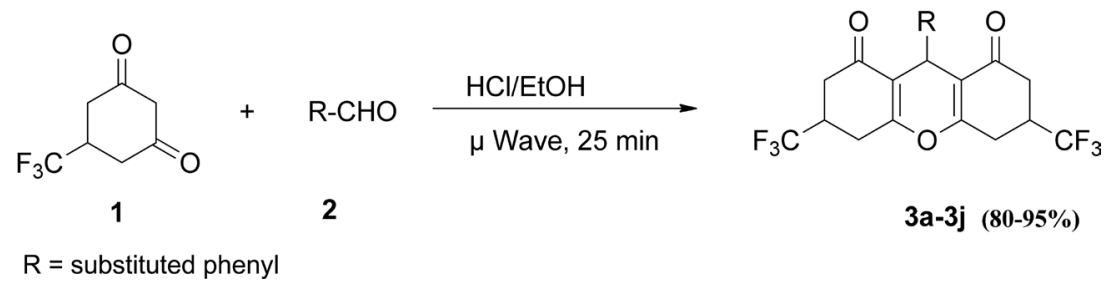

Scheme 2. Microwave assisted synthesis of $\mathbf{3} \mathbf{a}-\mathbf{3} \mathbf{j}$ and derivatives.

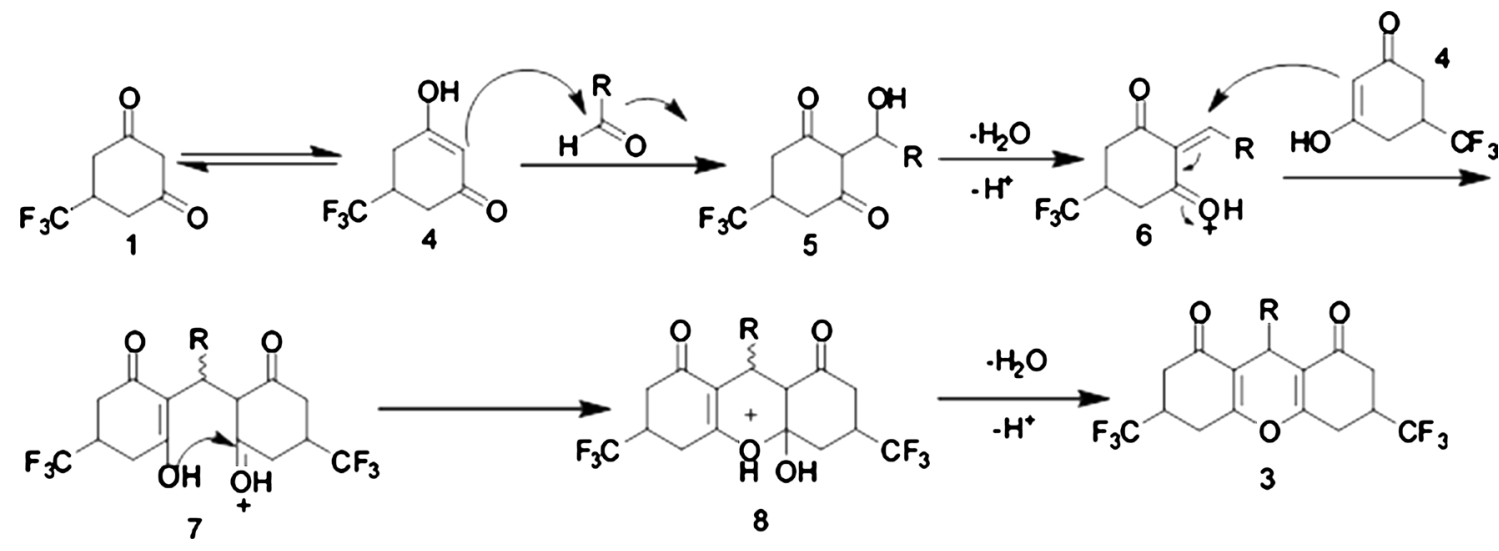

Figure 2. Suggested mechanism for the formation of xanthenedione.

spectrum. The NMR data are consistent with the structure of the expected structure. The tricyclic component displayed a typical chemical shift of $4.82 \mathrm{ppm}$ corresponding to the lone proton on the 9-position of the pyran core.

As suggested in Figure 2 the reaction is presumed to proceed by initial keto-enol equilibrium of compound 1 and 4 . Compound 4 then reacts with the aldehyde in a cross-aldol type manner to furnish the $\beta$-hydroxy ketone 5 , which under the acidic condition undergoes dehydration to the more stable intermediate 6 . The reaction of another equivalent of compound 4 with $\mathbf{6}$ is expected to give 7. Next, the oxygen atom of the enol form of 7 underwent intramolecular ring closure to give compound $\mathbf{8}$. The subsequent loss of water and regeneration of the acid catalyst gave the expected bis-trifluoromethyl xanthene dione 3.

\section{Conclusion}

A highly efficient introduction of a trifluoromethyl group into biologically active xanthenedione is achieved. It is worthy of note that nearly $20 \%$ of drugs approved annually by FDA contain one or more fluorine atoms, thus making the incorporation of fluorine into potential new drug entities attractive to medicinal chemists. The reaction of 5-trifluoromethyl cyclohexane-1,3-dione with substituted aromatic aldehydes in ethanol containing $1-2$ drops of $\mathrm{HCl}$, under microwave irradiation was facile, leading to good to excellent yields. The procedure is green, simple, and requires $25 \mathrm{~min}$ for the reaction to go to completion. The resulting bis-trifluoromethyl xanthene dione products constitute a novel series of synthetically using stable intermediates, that can be employed as precursors for pharmaceutical, agricultural, and material science applications. 


\section{Acknowledgements}

We are grateful to the United States Department of Education, Title III grant award to Tennessee State University for the financial support. Vanderbilt University, Nashville, TN is also gratefully acknowledged for their technical assistance for the maintenance of the Department of Chemistry's $400 \mathrm{MHz}$ Bruker NMR spectrometer.

\section{Conflicts of Interest}

The authors declare no conflicts of interest regarding the publication of this paper.

\section{References}

[1] Lipson, V.V., Desenko, S.M., Shirobokova, M.G. and Borodina, V.V. (2003) Synthesis of 9-Aryl-6,6-Dimethyl-5,6,7,9-Tetrahydro-1,2,4-Triazolo-[5,1-B]quinazolin-8(4H) Ones. Chemistry of Heterocyclic Compounds, 39, 1419-1427. https://doi.org/10.1023/B:COHC.0000008269.69460.ac

[2] Robinson, R. (1958) Chemistry of Brazilin and Haematoxylin. Bulletin de la Société chimique de France, 1, 125-134.

[3] Yen, C.-T., Nakagawa-Goto, K., Hwang, T.-L., Wu, P.-C., Morris-Natschke, S.L., Lai, W.-C., Bastow, K.F., Chang, F.-R., Wu, Y.-C. and Lee, K.-H. (2010) Antitumor Agents. 271: Total Synthesis and Evaluation of Brazilin and Analogs as Anti-Inflammatory and Cytotoxic Agents. Bioorganic \& Medicinal Chemistry Letters, 20, 1037-1039. https://doi.org/10.1016/j.bmcl.2009.12.041

[4] Huang, Y., Zhang, J. and Pettus, T.R.R. (2005) Synthesis of ( \pm )-Brazilin Using IBX. Organic Letters, 7, 5841-5844. https://doi.org/10.1021/ol0523749

[5] Manikannan, R., Venkatesan, R., Muthusubramanian, S., Yogeeswari, P. and Sriram, D. (2010) Pyrazole Derivatives from Azines of Substituted Phenacyl Aryl/Cyclohexyl Sulfides and Their Antimycobacterial Activity. Bioorganic \& Medicinal Chemistry Letters, 20, 6920-6924. https://doi.org/10.1016/j.bmcl.2010.09.137

[6] Bhaskara, N., Ankita, C., Anshika, L. and Jitender, M.K. (2015) Synthesis and Characterization of Hybrid Chloroquinoline-Xanthene Derivatives. Cogent Chemistry, 1, Article ID: 1071227. https://doi.org/10.1080/23312009.2015.1071227

[7] Giri, R., Goodell, J.R., Xing, C., Benoit, A., Kaur, H., Hiasa, H. and Ferguson, D.M. (2010) Synthesis and Cancer Cell Cytotoxicity of Substituted Xanthenes. Bioorganic \& Medicinal Chemistry, 18, 1456-1463. https://doi.org/10.1016/j.bmc.2010.01.018

[8] Parkin, D.M., Bray, F., Ferlay, J. and Pisani, P. (2002) Global Cancer Statistics. CA: A Cancer Journal for Clinicians, 55, 74-108. https://doi.org/10.3322/canjclin.55.2.74

[9] Faidallah, H.M., Khan, K.A. and Asiri, A.M. (2011) Synthesis and Biological Evaluation of New 3,5-di(trifluoromethyl)-1,2,4-triazolesulfonylurea and Thiourea Derivatives as Antidiabetic and Antimicrobial Agents. Journal of Fluorine Chemistry, 132, 870-877. https://doi.org/10.1016/j.jfluchem.2011.06.014

[10] Aytemir, M.D., Hider, R.C., Erol, D.D., et al. (2003) Synthesis of New Antimicrobial Agents; Amide Derivatives of Pyranones and Pyridinones. Turkish Journal of Chemistry, 27, 445-452.

[11] Yildirir, Y., Us, M.F., Colak, N., Özkan, H., Yavuz, S., Dişli, A., Öztürk, Ş. and Türker, L. (2009) The Synthesis and Investigation of the Antimicrobial Activity of 
Some New Phenylselanyl-1-(toluene-4sulfonyl)-1Htetrazole Derivatives. Medicinal Chemistry Research, 18, 91-97. https://doi.org/10.1007/s00044-008-9110-7

[12] Alyar, S. and Karacan, N. (2009) Synthesis, Characterization, Antimicrobial Activity and Structure-Activity Relationships of New Aryldisulfonamides. Journal of Enzyme Inhibition and Medicinal Chemistry, 24, 986-992. https://doi.org/10.1080/14756360802561220

[13] Wang, H., Lu, L., Zhu, S., Li, Y. and Cai, W. (2006) The Phototoxicity of Xanthene Derivatives against Escherichia coli, Staphylococcus aureus, and Saccharomyces cerevisiae. Current Microbiology, 52, 1-5. https://doi.org/10.1007/s00284-005-0040-z

[14] Qiao, Y.F., Okazaki, T., Ando, S., Mizoue, K., Kondo, K., Eguchi, T., et al. (1998) Isolation and Characterization of a New Pyrano[4',3':6,7]naphtho [1,2-b]xanthene Antibiotic FD-594. The Journal of Antibiotics, 51, 282-287.

https://doi.org/10.7164/antibiotics.51.282

[15] Limsuwan, S., Tripc, E.N., Kouwen, T.R.H.M., Piersma, S., Hiranrat, A., Mahabusarakam, W., et al. (2009) Rhodomyrtone: A New Candidate as Natural Antibacterial Drug from Rhodomyrtus tomentosa. Phytomedicine, 16, 645-651.

https://doi.org/10.1016/j.phymed.2009.01.010

[16] Kaya, M., Basar, E. and Colak, F. (2011) Synthesis and Antimicrobial Activity of Some Bisoctahydroxanthene-1,8-dione Derivatives. Medicinal Chemistry Research, 20, 1214-1219. https://doi.org/10.1007/s00044-010-9459-2

[17] Uchida, T., Kagoshima, Y. and Konosu, T. (2009) Amide Analogs of Antifungal Dioxane-Triazole Derivatives: Synthesis and in Vitro Activities. Bioorganic \& $\mathrm{Me}$ dicinal Chemistry Letters, 19, 2013-2017. https://doi.org/10.1016/j.bmcl.2009.02.036

[18] Biffinger, J.C., Kim, H.W. and Di Magno, S.G. (2004) The Polar Hydrophobicity of Fluorinated Compounds. ChemBioChem, 5, 622-627. https://doi.org/10.1002/cbic.200300910

[19] Choo, H., Chong, Y., Choi, Y., Mathew, J., Schinazi, R.F. and Chu, C.K. (2003) Synthesis, Anti-HIV Activity, and Molecular Mechanism of Drug Resistance of 1-2',3'-Didehydro-2',3'-dideoxy-2'-fluoro-4'-thionucleosides. Journal of Medicinal Chemistry, 46, 389-398. https://doi.org/10.1021/jm020376i

[20] Johnson, M.D., Chen, J. and Anderson, B.D. (2002) Investigation of the Mechanism of Enhancement of Central Nervous System Delivery of 2'- $\beta$-Fluoro-2',3'-Dideoxyinosine via a Blood-Brain Barrier Adenosine Deaminase-Activated Prodrug. Drug Metabolism \& Disposition, 30, 191-198.

[21] Tanaka, F., Fukuse, T., Wada, H. and Fukushima, M. (2000) The History, Mechanism and Clinical Use of Oral 5-Fluorouracil Derivative Chemotherapeutic Agents. Current Pharmaceutical Biotechnology, 1, 137-164. https://doi.org/10.2174/1389201003378979

[22] McCarter, J.D., Adam, M.J., Hartman, N.G. and Withers, S.G. (1994) In Vivo Inhibition of $\beta$-Glucosidase and $\beta$-Mannosidase Activity in Rats by 2-Deoxy-2-fluoro- $\beta$-glycosyl Fluorides and Recovery of Activity in Vivo and in Vitro. Biochemical Journal, 301, 343-348. https://doi.org/10.1042/bj3010343

[23] Darviche, F., Balalaie, S., Chadegani, F. and Salehi, P. (2007) Diammonium Hydrogen Phosphate as a Neutral and Efficient Catalyst for Synthesis of 1,8-Dioxo-Octahydroxanthene Derivatives in Aqueous Media. Synthetic Communications, 37, 1059-1066. https://doi.org/10.1080/00397910701196520

[24] Fan, X., Hu, X., Zhang, X. and Wang, J. (2005) $\mathrm{InCl}_{3} \cdot 4 \mathrm{H}_{2} \mathrm{O}$-Promoted Green Preparation of Xanthenedione Derivatives in Ionic Liquids. Canadian Journal of Chemistry, 83, 16-20. https://doi.org/10.1139/v04-155 
[25] Fan, X.-S., Li, Y.-Z., Zhang, X.-Y., Hu, X.-Y. and Wang, J.-J. (2005) $\mathrm{FeCl}_{3} \cdot 6 \mathrm{H}_{2} \mathrm{O}$ Catalyzed Condensation of Aromatic Aldehydes with 5,5-Dimethyl-1,3-Cyclohexanedione in Ionic Liquids. Chinese Journal of Organic Chemistry, 25, 1482-1486.

[26] Zhang, Z.-H. and Tao, X.-Y. (2008) 2,4,6-Trichloro-1,3,5-Triazine-Promoted Synthesis of 1,8-Dioxo-Octahydroxanthenes under Solvent-Free Conditions. Australian Journal of Chemistry, 61, 77-79. https://doi.org/10.1071/CH07274

[27] Davoodnia, A., Basafa, S. and Tavakoli-Hoseini, N. (2016) Neat Synthesis of Octahydroxanthene-1,8-Diones, Catalyzed by Silicotungstic Acid as an Efficient Reusable Inorganic Catalyst. Russian Journal of General Chemistry, 86, 1132-1136. https://doi.org/10.1134/S107036321605025X

[28] Javid, A., Heravi, M.M. and Bamoharram, F.F. (2011) One-Pot Synthesis of 1,8-Dioxo-Octahydroxanthenes Utilizing Silica-Supported Preyssler Nano Particles as Novel and Efficient Reusable Heterogeneous Acidic Catalyst. E-Journal of Chemistry, 8, 910-916. https://doi.org/10.1155/2011/980242

[29] Infante Lara, L., Sledge, A., Laradji, A., Cosmas, O. and Osheroff, N. (2017) Novel Trifluoromethylated 9-Amino-3,4-Dihydroacridin-1 (2H)-Ones Act as Covalent Poisons of Human Topoisomerase II $\alpha$. Bioorganic \& Medicinal Chemistry Letters, 27, 586-589. https://doi.org/10.1016/j.bmcl.2016.12.011

[30] Fadeyi, O.O. and Okoro, C.O. (2008) Synthesis of 5-(Trifluoromethyl) Cyclohexane-1,3-Dione and 3-Amino-5-(Trifluoromethyl) Cyclohex-2-en-1-One: New Trifluoromethyl Building Block. Tetrahedron Letters, 49, 4725-4727. https://doi.org/10.1016/j.tetlet.2008.05.120

[31] Fadeyi, O.O., Adamson, S.T., Myles, E.L. and Okoro, C.O. (2008) Novel Fluorinated Acridone Derivatives. Part 1: Synthesis and Evaluation as Potential Anticancer Agents. Bioorganic \& Medicinal Chemistry Letters, 18 4172-4176. https://doi.org/10.1016/j.bmcl.2008.05.078

[32] Apraku, J. and Okoro, C.O. (2019) Design, Synthesis and Anticonvulsant Evaluation of Fluorinated Benzyl Amino Enaminones. Bioorganic \& Medicinal Chemistry, 27, 161-166. https://doi.org/10.1016/j.bmc.2018.11.033

[33] Ajala, A.O. and Okoro, C.O. (2011) CoMFA and CoMSIA Studies on Fluorinated Hexahydropyrimidine Derivatives. Bioorganic \& Medicinal Chemistry Letters, 21, 7392-7398. https://doi.org/10.1016/j.bmcl.2011.10.008 